UDC 378.146

Olha V. Chyzhykova

$\mathrm{PhD}$ of Pedagogical Sciences, Associate Professor at the Department of Foreign and Business Ukrainian Languages State University of Economics and Technology, Kryvyi Rih, Ukraine

ORCID ID 0000-0002-4432-9743

olgalehina@ukr.net

\title{
PROVISION OF CONSTRUCTIVE FEEDBACK BY MEANS OF INFORMATION TECHNOLOGIES IN THE PROCESS OF FOREIGN LANGUAGE COMPETENCE DEVELOPMENT OF STUDENTS OF ECONOMIC SPECIALTIES
}

\begin{abstract}
The article explores the importance of forming constructive academic feedback via information technologies in the process of students' foreign language competence development. This article reports on theoretical substantiation and practical results of the experimental work on effective feedback provision in the process of students' foreign language communication skills development in higher education. The growing role of online space in constructive feedback designing is underlined. The author analyses scientific works in Scopus and Web of Science Databases in particular on academic feedback, its basic characteristics and its role in improving students' foreign language competence. The article highlights the importance of carefully designing feedback process in the course of learning English with the purpose to develop students' communication and problem-solving skills, improve their practical knowledge, enrich their professionally oriented vocabulary, and enhance other students' abilities resulting in a better FL competence. Particular attention is paid to methods, principles and conditions that enable effective feedback formation by means of information technologies. The main elements and types of constructive feedback are analyzed. The results of the experiment as well as their interpretation are offered. The participants of the experiment were 25 first-year students of 3 economic specialties learning English as a foreign language. The products of students' activities were analyzed to investigate the most effective ways of academic feedback. The participants presented their academic outcomes in the form of a short essay, a test, and projects. The experiment results showed improvement through the reduction of grammar and lexical error rates. The results showed the reduction of 4 error categories in general. The article presents the students' responses to different types of academic feedback (direct, indirect, metalinguistic, staff-tostudent, peer feedback) in the form of an online survey. The positive effect of feedback via information technologies on students' foreign language communication skills, professional-oriented vocabulary enrichment, English grammar skills, motivation to learn foreign languages, elaboration of educational products, self-assessment and self-improvement skills was recorded at the end of the study. The results of the experiment are discussed in light of the growing use of information technologies that enable constructive feedback provision in the process of foreign language competence development. The advantages and disadvantages of academic feedback provision by using information technologies are analyzed. Recommendations for educators and students are provided on the effective feedback formation in the process of foreign language study.
\end{abstract}

Keywords: academic feedback; foreign language; foreign language competence; communication skills; future economists; information technologies.

\section{INTRODUCTION}

Statement of the problem. Foreign language proficiency is considered to be a great benefit in the contemporary globalized world and on the labour market. Thus, the problem of foreign language competence development is becoming more and more vital in higher education. In practice, it is often found that the level of students' foreign language competence is not sufficient for the fulfillment of further professional activities and needs complementary support, including constructive feedback provision. Implementation of constructive feedback in a complex process of foreign language competence development plays an essential role, as it fosters improvement of foreign language communication skills. Taking into account modern realities and the active process of digitalization of higher education, provision of constructive feedback can be effectively organized by means of information technologies. 
Constructive feedback ensures efficiency of the learning process in higher education. It enables the learners to be active participants of the learning process and provides the development of students' elaboration, self-assessment and self-improvement. Provision of formative feedback has an important role. In foreign language learning it stimulates students' motivation, improvement of listening, writing, reading and speaking skills, grammar and vocabulary learning abilities. It can be of great assistance in the mastering of future specialists' foreign language communication skills. But in practice the stage of designing and implementation of constructive feedback is usually underestimated. A conventionally accepted form of feedback is an irreciprocal process of providing students with academic information and tasks followed by teacher's comments and assessment. Such form of feedback eliminates students' active participation and has little effect on improving their learning and academic achievements. Moreover, it often occurs in a situational context. Therefore, it is crucial for teachers to provide effective academic feedback on a regular basis and develop activities to encourage learners to improve their foreign language competence and to exercise elaboration, self-assessment and self-improvement skills. Students should be actively engaged in meaningful learning experience to improve their learning outcomes.

In recent years we can observe a growing role of information and communication technologies in the learning process. Information technologies are also successfully implemented in foreign language study. Thus, scholars emphasize the effective role of multimedia teaching technologies in the formation of foreign language competence [1] and English students' speaking ability [2]. Along with the improvement of essential language skills, technology-intensified language learning approach is aimed to promote learners' autonomy.

As information technology has an important role in different stages of the learning process [3, p. 135] we can take advantage of the technology use in the process of constructive academic feedback formation. From our perspective, information technology is a powerful tool that successfully helps in providing academic feedback on a regular basis. Technology also makes learning process student-centered. Since the link between learners' self-regulation, their learning outcomes, educational results and achievements (development of foreign language competence), technology, students' responses and teachers has not been investigated to the full extent yet, this study fills the gap by reporting how provision of constructive academic feedback via information technologies enables improvement of learners' foreign language competence, fosters elaboration, self-assessment and self-improvement skills.

The analysis of recent studies and publications. The problem of academic feedback formation has been studied by E. Belyaeva, D. Boud, Ph. Dawson, C. Gregoric, M. Henderson, J. McCarthy, S Merry, P. Mahoney, E. Molloy, A. Müller, P. Orsmond, M. Phillips, T. Ryan and others. Thus, A. Müller, C. Gregoric and D. Rowland designed a program of language development that complemented university support, focusing specifically on grammar-based proof-reading and error correction [4]. Conditions of the effective feedback in higher education have been studied by Henderson et al. The authors paid special attention to feedback design, capacity of the people involved and the institutional culture [5]. It is underlined that feedback should be learner-centered where collaborative learning and peer feedback take place [5], [6]. D. Boud and E. Molloy studied the phenomenon of student feedback in higher education and its positive influence on learning. The origins of academic feedback, characteristics and principles of sustainable feedback have been examined in the article [7]. S. Merry and P. Orsmond explored the provision of formative feedback using audio files, considering feedback as integral to the whole learning [8]. E. Belyaeva devoted her study to the corrective feedback strategies, error correction strategy in particular [9, p. 32]. Academic feedback in a distance course of foreign language as a key factor influencing the quality of education has been analyzed by N. Mulina [10].

The use of information technologies has been studied by S. Dintoe, S. Merry, F. Khodabandeh, P. Orsmond S. Sirkemaa and others. Among Ukrainian scientists that contributed to the informatization of the educational process are M. Gladun and M. Sablina, N. Hodovanets, I. Klak, M. Kostyuk, O. Krivoruchko, Yu. Opanasyuk, N. Yatseniuk, I.Zaiarna, and others. Scientific researches highlight such issues as benefits and difficulties of applying ICT in a university context, paying attention to different forms of e-learning [11], [12], [13]; development of students' skills and 
abilities in producing legal reasoning written texts [14]; essence of informatization of modern educational system, main features, aspects, strategies, tendencies, categories and consequences of information technology use in education [11], [15]. Computer supported collaborative learning as a technology that combines the best achievements of the traditional educational system and ICT is studied by M. Gladun and M. Sablina. This approach increases motivation for those students who are not interested in improving knowledge and skills through traditional didactic tools, enabling realization of students' creative potential, development of both subject and key competencies. The use of such online tools as Skype, Trello, Padlet, LearningApps is described in the article [13, p.34].

Numerous studies proved efficacy of technology use in the educational process [1], [3], [16], [17]. As mentioned by S. Sirkemaa, technology is widely used in different fields and activities, and this is also the case in education. It is rightly stressed that modern technology has gradually become a part of the learning process, including communication between students and teachers, who rely on information technology [3]. However, devices themselves cannot shift instructional practices or improve student learning. Technology should be used through shifting to practice and linked to content objectives [16]. I. Klak and N. Yatseniuk in their turn justified the positive role of multimedia learning technologies in the formation of teachers' foreign language communicative competence. The authors analyzed a number of advantages of information technology use, including intensifying the development of students' intellectual and creative abilities, enhancing the motivation for learning and future professional activity, flexibility of thinking, provision of individual approach and others [1].

In the frame of our study, scientific research on the use of online spaces and specifics of elearning in foreign language learning is of special interest. Thus, the use of information and communication tools in the process of interactive technology implementation in teaching English (including Internet projects, multimedia tools, use of audiovisual Internet sources) is studied by $\mathrm{N}$. Hodovanets [18]. D. Gónzalez O., Jh. Molina and B. Cardona explored the influence of ProjectBased Learning on students' oral proficiency by using audiovisual production projects (a podcast, a digital storytelling and a short film), indicating positive results showing marked improvement [17]. S. Sirkemaa suggested the use of video in learning situations, which is especially effective for adult students, as it may provide flexibility to learners and remove barriers for acquiring a foreign language, enabling the implementation of a richer variety of teaching methods [3, p. 135].

Despite numerous studies on designing academic feedback and the effective role of information technologies in education, less attention is paid to the formation of constructive feedback by means of information and communication technologies in developing students' foreign language competence.

The purpose of this article is to reveal the role and main features of effective academic feedback formation by means of information and communication technologies in the process of students' foreign language competence development and to substantiate their use in teaching English to future economists.

\section{RESEARCH METHODS}

In our research we used the following methods: theoretical analysis of scientific works to determine the nature of academic feedback and its main characteristics; empirical methods - survey, questioning, observations and analysis of products of students' activities (tests, essays, individual and group projects), a self-assessment method to identify the effective ways of students' constructive feedback formation by means of information technologies in their educational activity.

The participants of the research were 25 first-year students of specialties "Entrepreneurship, Trade and Stock Exchange Activity", "Accounting and Taxation" and "Finance, Banking and Insurance". The age of students was from 17 to 19. The experiment was conducted on the basis of Kryvyi Rih Economic Institute. Participants were given a test (pre-test) and wrote a short essay, which were analyzed for errors. This procedure was repeated for the second time at the end of the study. In the process of our exploration students conducted projects on professionally-oriented 
topics further presented for staff and peer review. Error rates were again evaluated with a post test and second essay writing after the provision of academic feedback by means of information and communication technologies.

Different types of feedback provision were evaluated by the participants in the form of an online questioning to reflect on the results of the experiment.

\section{FINDINGS}

\subsection{The process of effective academic feedback formation}

Formation of constructive academic feedback is an essential aspect of foreign language education. It enables students to develop skills of self-assessment and self-improvement, motivates students for learning English as a foreign language and elaborating the designed educational projects. In general, it can help improve foreign language literacy and communication skills. In modern conditions of a world quarantine, when many countries had to turn to distant teaching, electronic tools in providing academic feedback are of great importance. Digital learning has become an integral part of higher education.

In scientific research academic feedback is defined as a key factor influencing the quality of education and as the influence of the results of the system functioning on the nature of its functioning [10]; as "a complex process in which the learner needs to attend to, and make sense of, information about the quality of their performance in order to improve future work or learning strategies" [5]; as an effective means to improve "self-mastery over linguistic errors", thus developing learners' communication skills (including writing skills) [4]; as student self-regulation to frame a curriculum (day to day practices within the curriculum), underlying such challenges of feedback framework as generation of new ideas, the practice of learners and developing judgment as central concerns [7]. In our research under "academic feedback in foreign language study" we imply not only the process of monitoring students' learning achievements and outcomes, but also a complex process of pedagogical interaction leading to the development of learners' foreign language competence. Foreign language competence is interpreted as a high level of practical knowledge and skills of a foreign language that allow a future specialist to fulfill professional activities at a high level in the scope of intercultural communication [19]. Among significant components of foreign language competence scholars distinguish linguistic, language, discourse, strategic, socio-cultural, educational and cognitive competences [20, p. 176]. Being a complex integrative dynamic personal formation that identifies a future specialist's ability to use foreign language proficiency in future professional practice, foreign language competence is usually developed by the following stages: formative, control, corrective and final. Basic knowledge and abilities necessary for successful foreign language communication and the possibility to use this knowledge in practice are acquired at the formative stage. We believe that such activities as collaborative learning (team-based activities, group and pair activities), interactive technologies (case-based learning, simulations, problem solving, debates, project-based method, business games and round tables) aim to develop learners' foreign language competence. Monitoring of students' knowledge and skills learnt at the first stage is fulfilled at the control stage. At the corrective stage essential knowledge and skills necessary for successful professional communication are mastered through communicative situation training. Final control is carried out at the last stage. So, resulting from everything mentioned above, academic feedback is an essential component of a complex process of foreign language competence development, which is of great importance at the control, corrective and final stages.

A brief scheme of constructive feedback formation by means of information technologies in the process of learning English by students of economic specialties is presented in Figure 1.

The scheme demonstrates teacher-students interaction and the link between learners' selfregulation and learning outcomes (foreign language competence improvement) by providing constructive academic feedback via information technologies. 


\begin{tabular}{|c|c|c|c|}
\hline \multicolumn{4}{|c|}{$\begin{array}{l}\text { Principles } \\
\text { feedback is carefully and instructionally designed [5]; } \\
\text { it aims to master learners' foreign language competence; } \\
\text { it develops students' self-assessment and self-managerial skills; it is oriented on students' } \\
\text { success[10]; it stimulates motivation for learning foreign languages; } \\
\text { it provides learners with support to develop feedback literacy and critical thinking; } \\
\text { it reduces the gap between the existing and the desired levels of foreign language } \\
\text { proficiency [10]. }\end{array}$} \\
\hline 75 & & & II \\
\hline $\begin{array}{l}\text { Teacher } \\
\text { facilitates } \\
\text { collaborative learning, } \\
\text { encourages self- } \\
\text { assessment skills, } \\
\text { stimulates motivation } \\
\text { and development of } \\
\text { communication skills, } \\
\text { promotes elaboration } \\
\text { skills. }\end{array}$ & $\begin{array}{l}\quad \text { Information } \\
\quad \text { technology } \\
\text { educational } \\
\text { platforms; } \\
\text { software; } \\
\text { educational online } \\
\text { services; } \\
\text { telecommunication } \\
\text { applications. }\end{array}$ & $\begin{array}{l}\quad \text { Academic } \\
\quad \text { feedback } \\
\text { written, audio; } \\
\text { staff-to-student, } \\
\text { peer-to-peer; } \\
\text { formative, } \\
\text { summative; } \\
\text { direct, indirect, } \\
\text { metalinguistic. }\end{array}$ & $\begin{array}{l}\quad \text { Students } \\
\text { develop self- } \\
\text { assessment skills, } \\
\text { collaborate, } \\
\text { elaborate the } \\
\text { work done, } \\
\text { master foreign } \\
\text { language } \\
\text { competence; are } \\
\text { active in the } \\
\text { feedback process }\end{array}$ \\
\hline & & & \\
\hline \multicolumn{4}{|c|}{$\begin{array}{l}\text { Conditions } \\
\text { regular, sufficient and detailed character of feedback; active position of learners in the feedback } \\
\text { process [10]; } \\
\text { feedback is related to the purpose of task evaluation and criteria; } \\
\text { it is understandable for the student and related to future tasks, } \\
\text { it is focused on educational purposes and then on assessment [10]; } \\
\text { it is focused on foreign language skills and communicative competence development; } \\
\text { feedback meets the different needs of learners and ensures consistency and quality; } \\
\text { participants have access to appropriate technologies; information provided is usable [5]; } \\
\text { a variety of sources are used in the feedback process [5]. }\end{array}$} \\
\hline
\end{tabular}

Figure 1. Constructive feedback formation by means of information technologies in the process of learning English by students of economic specialties

Scholars distinguish the following types of academic feedback: written and audio [8]; staff-tostudent feedback, peer-to-peer feedback in class and online [6]; formative and summative feedback [10]; direct (direct teacher's correction with an overall mark or scores and a brief assessment comment); indirect (the use of error code to indicate clearly to students the error location without providing the corrected form) or metalinguistic strategy (providing a student with an explicit comment concerning the error using error codes for error identification and self-editing) and reformulation. Thus, direct feedback saves time and can bring an immediate insight and short-term accuracy improvement. Indirect feedback is more oriented on students' problem-solving skills, encourages students to reflect on the selected linguistic tools and leads to long-term learning. However, it may cause difficulties in self-correction [4], [9]. Electronic forms of feedback are more easily archived, copied and distributed for quality assurance purposes [8].

The general purpose of foreign language education is "to develop the ability to communicate" [21]. But numerous additional aims are worth mentioning: personal development of the individual [21], development of personal motivation, self-confidence, creative abilities, critical thinking, communication, intercultural and interaction skills etc. In this sense a thoroughly designed and successfully implemented academic feedback results in improving the level of foreign language 
proficiency, thus developing students' basic languages skills, students' autonomy, critical thinking, elaboration, self-managerial and self-improvement skills.

\subsection{The application of academic feedback by means of information technology in the process of learning English}

In our research we used such types of academic feedback by means of information and communication technologies as:

- telecommunication applications:

Viber messenger for direct and indirect written staff-to-student feedback;

the telecommunications application Skype for metalinguistic and indirect audio and written feedback;

Zoom platform for video and audio conferencing, for peer-to-peer audio feedback and staff-to-student feedback, both direct and indirect;

- educational platform:

Moodle learning platform for metalinguistic and direct audio and written feedback;

- educational online services for direct feedback:

https://www.britishcouncil.org;

https://www.englishpage.com;

http://englishmedialab.com;

http://english.ua;

- e-mail for direct written feedback and metalinguistic strategy.

We applied the designed error code presented in Table 1:

Table 1

Error code applied in the process of academic feedback implementation while learning English

\begin{tabular}{|l|l|l|}
\hline Error code & Error category & Explanation / Examples \\
\hline V (v/aux; v/l) & verb (auxiliary, link verbs) & to distribute, to be interested, do, does \\
\hline N (N/pl) & noun (noun/plurals) & condition, supply, advice \\
\hline Pron & pronoun & he, him, this \\
\hline Num & numeral & one, the first \\
\hline Adj & adjective & urgent, interesting, useful \\
\hline Adv & adverb & correctly \\
\hline Conj & conjunction & and, that, but, neither ... nor \\
\hline Prep & preposition & at, on, in \\
\hline Art & article & a, an, the, zero \\
\hline s/v & subject-verb agreement & $\begin{array}{l}\text { Subjects and verbs must agree with one } \\
\text { another in number: he was, people are }\end{array}$ \\
\hline SofT & Sequence of Tenses & he said that he would come \\
\hline Pass & Passive Voice & a letter is written \\
\hline Sent & Sentence & $\begin{array}{l}\text { sentence to be revised; the length of a } \\
\text { sentence }\end{array}$ \\
\hline St & Stylistic error & $\begin{array}{l}\text { Confusing the meaning of similar sounding } \\
\text { words (than / then, affect / effect); formal or } \\
\text { informal style etc. }\end{array}$ \\
\hline
\end{tabular}

Having summarized and calculated the quality of the errors in each category we were able to make a comparative analysis. The analysis of error rate on the basis of the comparison of pre-test and post-test and of the products of educational activities (essays and projects) allows us to speak about positive changes between initial error rates and final error rates results. Thus, at the initial stage in the pre-test and first essay writing we revealed typical errors, including: incorrect use of 
verb tenses (past simple instead of present perfect, omission of auxiliary verbs etc.); abnormalities in the system of adjectives (degrees of comparison) and pronouns (possessive versus objective case of personal pronouns); misunderstanding of linguistic features of professional terms; mistakes in the plural forms of nouns, use of the passive voice of the verb, syntactic errors and stylistic abnormalities. After completing our study, we observed the error rate reduction. It is manifested in the understanding and correct use of grammatical categories, language expressions, the ability to express one's own point of view, the correct use of lexical units and word order. In a qualitative estimation it constituted the reduction of low level of language literacy (from $28 \%$ to $8 \%$ ) and middle level (from 52\% to 16\%), the growth of sufficient level (from $12 \%$ to 56\%) and high level (from $8 \%$ to $20 \%$ ). We also recorded 4 fewer error categories on average (in comparison with a relatively large initial error rate with verbs (tense forms and voice category), nouns, adjective (degrees of comparison) and stylistic errors).

We have summarized advantages and disadvantages (difficulties) we saw in the process of feedback provision by means of information technologies in teaching English. Among advantages should be mentioned:

- individualized character;

- opportunities to apply different types of feedback to meet students' needs;

- development of students' foreign language competence;

- development of students' elaboration, self-improvement and self assessment skills;

- motivation for learning languages;

- effectiveness for self-editing;

- development of computer literacy.

Disadvantages are the following:

- demands detailed and careful preparation for its designing and implementation;

- time-consuming;

- depends on the availability of the Internet access, telecommunication applications and informational tools to all the participants.

To confirm our results, we also conducted an online survey with the students to find out their attitude towards the use of academic feedback provided via information technologies. The questionnaire contained information about types of the feedback provided ("What was the most effective type of academic feedback?") and its influence on students' foreign language communication abilities, motivation, self-assessment and elaboration skills (reflective comments concerning their attitude to the feedback type).

Overall, the students responded very positively to the feedback provided by means of information technologies. The survey outcomes demonstrate that students of economic specialties preferred indirect (48\%) and metalinguistic (36\%) feedback, with only 16\% of respondents (mostly with low level of language proficiency) giving preference to direct feedback. The students would like to receive more feedback in the format of peer feedback (56\%) in comparison with traditional staff-to-student one (44\%). We also recorded that peer feedback is of great interest for learners with preference to educational platforms (40\%) and telecommunication applications (36\%). Collaborative learning was also positively perceived by students. The respondents also recorded positive effect of feedback provided via information technologies on their foreign language competence, motivation, self-assessment, elaboration skills and self-improvement at the end of the experiment. The data of the survey are presented in Table 2.

Table 2

\section{Students' responses to the academic feedback provision by means of information technologies} in the process of learning English

\begin{tabular}{|l|l|lr|}
\hline $\begin{array}{l}\text { Type of academic } \\
\text { feedback }\end{array}$ & $\begin{array}{l}\text { Number of } \\
\text { respondents with } \\
\text { positive attitude to } \\
\text { the feedback type }\end{array}$ & $\begin{array}{l}\text { Students reflective comments concerning their } \\
\text { attitude to the feedback }\end{array}$ & \\
\hline
\end{tabular}




\begin{tabular}{|c|c|c|}
\hline Direct & 4 & $\begin{array}{l}\text { effective for short-time learning } \\
\text { more concentrated on the assessment } \\
\text { more objective character of a grade } \\
\text { individualized } \\
\text { attention to the variety of errors } \\
\text { makes correction clearer } \\
\text { helps some students to process information better } \\
\text { fast improvement of grammar and writing skills } \\
\text { (syntax) }\end{array}$ \\
\hline Indirect & 12 & $\begin{array}{l}\text { helps to edit outcomes more successfully } \\
\text { sometimes can cause misunderstandings } \\
\text { needs more time } \\
\text { better for rule memorizing } \\
\text { individualized } \\
\text { develops problem solving and creative skills } \\
\text { successfully maintains reflection } \\
\text { improves professional lexicon and boosts vocabulary } \\
\text { learning skills }\end{array}$ \\
\hline Metalinguistic & 9 & $\begin{array}{l}\text { helps focus attention on the variety of errors } \\
\text { attracts attention to details } \\
\text { useful explanations that make correction easier } \\
\text { improves grammatical awareness }\end{array}$ \\
\hline staff-to-student & 11 & $\begin{array}{l}\text { teacher is an experienced marker of the work } \\
\text { more detailed and accurate } \\
\text { professional explanations } \\
\text { aims at fast improvement of foreign language } \\
\text { communication skills }\end{array}$ \\
\hline peer feedback & 14 & $\begin{array}{l}\text { helpful tips } \\
\text { less stressful } \\
\text { competitive and collaborative } \\
\text { develops open communication and dialog skills } \\
\text { fosters fluency and improvement of learning outcomes }\end{array}$ \\
\hline $\begin{array}{l}\text { online } \\
\text { educational } \\
\text { platforms, } \\
\text { telecommunication } \\
\text { applications, } \\
\text { educational online } \\
\text { services. }\end{array}$ & 10 & $\begin{array}{l}\text { successfully maintains reflection } \\
\text { more convenient } \\
\text { develops self-assessment and elaboration skills helps } \\
\text { to learn how to work in a team } \\
\text { stimulates motivation for learning } \\
\text { immediate character } \\
\text { facilitates enrichment of professionally oriented } \\
\text { vocabulary }\end{array}$ \\
\hline
\end{tabular}

The following recommendations for teachers and students can be given concerning academic feedback provision by means of information technologies: students individual skills and needs should be taken into account; a constructive feedback design needs time and thorough preparation; it should be focused on educational purposes and then on assessment; different types of feedback should be applied at different stages of foreign language learning; peer feedback and collaborative learning can be of great interest for learners; learners should be active participants of the feedback process.

\section{CONCLUSIONS AND PROSPECTS FOR FURTHER RESEARCH}


Academic feedback is focused on educational purposes and aims to enhance language proficiency. Feedback activates cognitive mechanisms, helps to transfer already obtained knowledge and experience to new practical situations, reveals gaps and drawbacks in students' knowledge and communication skills. In our study academic feedback in teaching a foreign language is viewed as a complex process of pedagogical interaction, which leads to successful development of students' foreign language competence.

Academic feedback can be effectively provided by means of information technologies. The use of ICT in order to implement constructive feedback in the process of improving students' foreign language competence is an innovative pedagogical approach that aims to implement principles of personally oriented and developmental learning and provide significant advantages over traditional forms and methods. This approach is characterized by students' active participation and autonomy, application of different types of feedback to meet students' needs in correction, focus on mastering of foreign language communication skills, computer literacy and motivation for learning languages. Constructive feedback formation by means of information technologies in the process of learning English should be implemented according to special pedagogical principles and conditions such as careful design of feedback process, focus on learners' foreign language competence development; students' self-assessment and self-managerial skills; support for students in the development of feedback literacy and foreign language proficiency; reduction of the gap between the existing and the desired levels of foreign language competence.

The experiment conducted with the first-year students of economic specialties resulted in the general error rate reduction in 4 error categories. Moreover, academic feedback via online spaces enabled students to develop their foreign language competence, self-assessment, self-improvement and elaboration skills. Overall, it can help improve foreign language literacy and communication skills. In the frame of our study different types of academic feedback provision developed open dialog skills, fostered fluency and improvement of learning outcomes, facilitated enrichment of professionally oriented vocabulary, promoted improvement of grammar and writing skills.

The respondents underlined the preference of peer feedback with the use of educational platforms and telecommunication applications for effective feedback provision. Collaborative learning was also positively perceived by the students. The usage of information tools in feedback process gives opportunities to apply different types of feedback to meet students' needs, fosters self-editing practice, computer and foreign language literacy.

Among different types of feedback (indirect, direct, metalinguistic, peer-to-peer, staff-tostudent) indirect feedback was evaluated as helpful for successful outcomes editing and problemsolving, but sometimes causing misunderstandings. In this case other types of feedback (metalinguistic or direct) with more clear and explicit explanation will be more efficient. The type of feedback provision also depends upon the level of students' language proficiency.

Thus, provision of academic feedback via ICT in teaching English gives an opportunity to meet students' individual needs in correction, increases students' motivation, meets the requirements of student-centered learning, develops foreign language competence.

Further research will be connected with the development of students' creative abilities by means of information and communication technologies while learning foreign languages and the role of constructive academic feedback implementation in this process.

\section{REFERENCES (TRANSLATED AND TRANSLITERATED)}

[1] I. Ye. Klak, and N. I. Yatseniuk, "Forming the prospective foreign language teachers'communicative competence by means of multimedia teaching technologies", Information Technologies and Learning Tools, vol. 76, no.2, pp. 163-176, 2020, [Online]. Available: https://journal.iitta.gov.ua/index.php/itlt/issue/view/105 (in Ukrainian).

[2] F. Khodabandeh, "The impact of storytelling techniques through virtual instruction on English students' speaking ability", Teaching English with Technology, 18(1), pp.24-36, 2018. (in English)

[3] S. J. Sirkemaa, "Digital Learning Environment: Experiences from Using video in Learning Process", International Journal of Education and Information Technologies, vol. 11, pp. 134-137. 2017, [Online]. Available: http://www.naun.org/main/NAUN/educationinformation/2017/a362008-033.pdf. ( in English) 
[4] A. Müller, C. Gregoric and D. R. Rowland, "The impact of explicit instruction and corrective feedback on ESL postgraduate students' grammar in academic writing”, Journal of Academic Language \& Learning, vol. 11, no. 1, pp. A125-A144, 2017, [Online]. Available: https://journal.aall.org.au/index.php/jall/article/view/442/274 (in English)

[5] M. Henderson et al., "Conditions that enable effective feedback", Higher Education Research \& Development, vol. 38, no.7, pp. 1401-1416, 2019, doi: https://doi.org/10.1080/07294360.2019.1657807. (in English)

[6] J. McCarthy, "Enhancing feedback in higher education: Students' attitudes towards online and in-class formative assessment feedback models", Active Learning in Higher Education, vol. 18, no. 2, 2017, doi: https://doi.org/10.1177/1469787417707615. (in English)

[7] D. Boud and E. Molloy, "Rethinking models of feedback for learning: The challenge of design", Assessment \& Evaluation in Higher Education, no. 38(6), pp. 698-712, 2013, doi:10.1080/02602938.2012.691462. (in English)

[8] S. Merry and P. Orsmond, "Students' Attitudes to and Usage of Academic Feedback Provided Via Audio Files", Bioscience Education, vol. 11, issue 1, pp. 1-11, 2008, doi: https://doi.org/10.3108/beej.11.3. (in English)

[9] E. Belyaeva, "Postgraduate students academic writing: corrective feedback strategies", Translation and Comparative Linguistics, vol. 12, pp. 32 -36, 2016. (in English)

[10] N. I. Mulina, "Organization of effective feedback in distance learning of foreign languages", Humanitarian Bulletin of Pereyaslav Khmelnytsky State Pedagogical University named after Hryhoriy Skovoroda, vol. I (43): Thematic issue "Higher Education of Ukraine in the Context of Integration into the European Educational Space", K .: Gnosis, pp. 609-616, 2013. (in Ukrainian).

[11] Yu. Opanasyuk, "Main directions of informatization of education", Higher Education Of Ukraine, no. 4, 45-50, 2016, [Online]. Available: file:///C:/Users/Owner/Desktop/vou_2016_4_9.pdf. (in Ukrainian).

[12] S. S. Dintoe, "Information and communication technology use in higher education: Perspectives from faculty", International Journal of Education and Development using Information and Communication Technology, vol. 14, Issue 2, pp. 121-166, 2018, [Online]. Available: https://files.eric.ed.gov/fulltext/EJ1190071.pdf. (in English)

[13] M. Gladun, M. Sablina, "Modern online instruments of interactive education as technology of cooperation", Open educational e-environment of modern University, no. 4, pp. 33-43, 2018, [Online]. Available: https://openedu.kubg.edu.ua/journal/index.php/openedu/article/view/125/170. (In Ukrainian)

[14] I. S. Zaiarna, "The model for e-teaching english reasoning writing to law students based on LMS moodle", Information Technologies and Learning Tools, vol 76, no.2, pp. 152-162, 2020, [Online]. Available: https://journal.iitta.gov.ua/index.php/itlt/article/view/3332. (in English)

[15] O. V. Krivoruchko, M.A. Kostyuk, "Modern tendencies of informatization of educational process", Science and Education a New Dimension., VI (20), Issue: 172, pp.29-32, 2018, [Online]. Available: https://seanewdim.com/uploads/3/4/5/1/34511564/httpsdoi.org10.31174send-nt2018-172vi20-07.pdf. (in Ukrainian).

[16] J. Prince, "Promising Instructional Practices for English Language Learners", Journal of Information Technology Education: Innovations in Practice, vol. 17, pp. 001-021, 2018, doi: https://doi.org/10.28945/3937 (in English)

[17] D. Gónzalez O., Jh. Molina and B. Cardona, "Project-based learning to develop oral production in English as a foreign language", International Journal of Education and Information Technologies, vol. 11, pp. 87-96, 2017. (in English)

[18] N. I Hodovanets, "Usage of modern information technologies in teaching a foreign language", Scientific Bulletin of Uzhhorod National University, Issue 35, pp. 48-50, 2015, [Online]. Available: https://dspace.uzhnu.edu.ua/jspui/bitstream/lib/11637/1. (in Ukrainian).

[19] J.-U. Sandal, T. Detsiuk and N. Kholiavko, "Developing foreign language communicative competence of engineering students within university extracurricular activities", Advanced Education, Issue 14, pp. 19-28, 2020, [Online]. Available: file:///C:/Users/Owner/Desktop/192411-Article\%20Text-457933-1-10-20200527.pdf. (in English)

[20] R. A. Valeeva, O. V. Baykova, and A. K. Kusainov, "Foreign Language Professional Communicative Competence as a Component of the Academic Science Teacher's Professional Competence", International Journal of Environmental \& Science Education, 11(3), 173-183, 2016, [Online]. Available: https://files.eric.ed.gov/fulltext/EJ1092224.pdf. (in English)

[21] M. Byram, P. Holmes, and Savvides, N., "Intercultural communicative competence in foreign language education: questions of theory, practice and research", The Language Learning Journal, 41:3, 251-253, 2013. doi: 10.1080/09571736.2013.836343. (in English)

\section{ЗАБЕЗПЕЧЕННЯ КОНСТРУКТИВНОГО ЗВОРОТНОГО ЗВ'ЯЗКУ ЗАСОБАМИ ІНФОРМАЦІЙНИХ ТЕХНОЛОГІЙ У ПРОЦЕСІ РОЗВИТКУ ІНШОМОВНОЇ КОМПЕТЕНТНОСТІ СТУДЕНТІВ ЕКОНОМІЧНИХ СПЕЦАЛЬНОСТЕЙ}




\title{
Чижикова Ольга Вікторівна
}

кандидат педагогічних наук, доцент кафедри іноземних та ділової української мов,

Державний університет економіки і технологій, м. Кривий Ріг, Україна

ORCID ID 0000-0002-4432-9743

olgalehina@ukr.net

\begin{abstract}
Анотація. У статті розглядається важливість формування конструктивного зворотного зв'язку під час розвитку іншомовної компетентності студентів; наводяться теоретичні обгрунтування i практичні результати експериментальної роботи щодо забезпечення ефективного зворотного зв'язку під час розвитку іншомовних комунікативних навичок студентів у вищій школі; підкреслюється зростаюча роль онлайн простору в конструюванні академічного зворотного зв'язку. Автор аналізує наукові роботи, зокрема в базах даних Scopus i Web of Science, щодо академічного зворотного зв'язку, його основних характеристик та ролі у вдосконаленні іншомовної компетентності студентів. У статті акцентовано увагу на важливості ретельної розробки зворотного зв'язку під час вивчення англійської мови як іноземної майбутніми фахівцями $з$ метою вдосконалення комунікативних навичок студентів, навичок вирішення навчальних проблем, удосконалення практичних знань студентів, збагачення професійно орієнтованого словникового запасу та інших здібностей студентів, що призводять до розвитку іншомовної комунікативної компетентності. Особлива увага приділяється методам, принципам і умовам, які дозволяють формувати ефективний зворотний зв'язок за допомогою інформаційних технологій. У статті аналізуються основні елементи конструктивного зворотного зв'язку. Наведені результати проведеного експерименту, а також їх інтерпретація. Учасниками експерименту стали 25 першокурсників 3 економічних спеціальностей, які вивчають англійську мову як іноземну. Під час експериментальної роботи були проаналізовані продукти навчальної діяльності студентів 3 метою виявлення найбільш ефективних способів академічного зворотного зв'язку. Учасники представили свої результати у вигляді короткого есе, тесту, індивідуальних і групових проєктів. Результати експерименту виявили тенденцію до зниження рівня граматичних і лексичних помилок. У статті наведено відповіді студентів на різні види академічного зворотного зв'язку (прямий, непрямий, металінгвістичний) у формі онлайн опитування. Позитивний вплив зворотного зв'язку за допомогою інформаційних технологій на розвиток мотивації студентів до вивчення іноземної мови, комунікативних навичок, збагачення словникового запасу, граматичних та навичок самооцінки й самовдосконалення було зафіксовано в кінці дослідження. Результати експерименту подано в світлі зростаючого використання інформаційних технологій, що забезпечують конструктивний зворотний зв'язок під час розвитку іншомовної компетентності. Проаналізовано переваги і недоліки забезпечення академічного зворотного зв'язку за допомогою інформаційних технологій. Автор надає рекомендації для викладачів і студентів щодо формування ефективного зворотного зв'язку під час вивчення іноземної мови.
\end{abstract}

Ключові слова: академічний зв'язок; іноземна мова; іншомовна компетентність; майбутні економісти; інформаційні технології.

\section{ОБЕСПЕЧЕНИЕ КОНСТРУКТИВНОЙ ОБРАТНОЙ СВЯЗИ С ПОМОЩЬЮ ИНФОРМАЦИОННЫХ ТЕХНОЛОГИЙ В ПРОЦЕССЕ РАЗВИТИЯ ИНОЯЗЫЧНОЙ КОМПЕТЕНТНОСТИ СТУДЕНТОВ ЭКОНОМИЧЕСКИХ СПЕЦИАЛЬНОСТЕЙ}

\author{
Чижикова Ольга Викторовна \\ кандидат педагогических наук, доцент кафедры иностранных и делового украинского языков \\ Государственный университет экономики и технологий, г. Кривой Рог, Украина \\ ORCID ID 0000-0002-4432-9743 \\ olgalehina@ukr.net
}

\begin{abstract}
Аннотация. В статье рассматривается важность формирования конструктивной обратной связи в процессе развития иноязычной компетентности студентов; приводятся теоретические обоснования и практические результаты экспериментальной работы по обеспечению эффективной обратной связи в процессе развития коммуникативных навыков студентов при изучении иностранного языка в высшей школе; подчеркнута возрастающая роль онлайн пространства в конструировании академической обратной связи. Автор анализирует научные работы, в частности в базах данных Scopus и Web of Science, относительно академической обратной связи и ее основных характеристиках и роли в совершенствовании иноязычной компетентности студентов. Подчеркивается важность тщательной разработки обратной связи в процессе изучения английского языка будущими специалистами с целью усовершенствования коммуникативных
\end{abstract}


навыков студентов, навыков решения учебных проблем, совершенствования практических знаний, обогащения профессионально ориентированного словарного запаса и других способностей студентов, которые приводят к развитию иноязычной коммуникативной компетентности. Особое внимание уделяется методам, принципам и условиям, которые позволяют формировать эффективную обратную связь с помощью информационных технологий. В статье анализируются основные элементы конструктивной обратной связи. Приведены результаты проведенного эксперимента, а также их интерпретация. Участниками эксперимента стали 25 первокурсников 3 экономических специальностей, изучающих английский язык как иностранный. В процессе экспериментальной работы были проанализированы продукты учебной деятельности студентов с целью выявления наиболее эффективных способов академической обратной связи. Участники представили свои результаты в виде эссе, теста, индивидуальных и групповых проектов. Результаты эксперимента выявили тенденцию к снижению уровня грамматических и лексических ошибок. В статье представлены ответы студентов различных видов академической обратной связи (прямой, непрямой, металингвистической) в форме онлайн-опроса. Положительное влияние обратной связи посредством информационных технологий на развитие мотивации студентов к изучению иностранного языка, коммуникативных навыков, обогащение словарного запаса, грамматических и навыков самооценки и самосовершенствования было зафиксировано в конце исследования. Результаты эксперимента отображены в свете растущего использования информационных технологий, обеспечивающих конструктивную обратную связь в процессе развития иноязычной компетентности. Проанализированы преимущества и недостатки академической обратной связи с помощью информационных технологий. Автор предоставляет рекомендации для преподавателей и студентов относительно формирования эффективной обратной связи в процессе изучения иностранного языка.

Ключевые слова: академическая обратная связь; иностранный язык; иноязычная компетентность; коммуникативные навыки; будущие экономисты; информационные технологии.

This work is licensed under Creative Commons Attribution-NonCommercial-ShareAlike 4.0 International License. 